\title{
Kemampuan Pemahaman Konsep Matematika Melalui Model Pembelajaran Auditory Intellectually Repetition (AIR) Pada Siswa
}

\author{
St. Hasmiah Mustamin ${ }^{1)}$, Andi Kusumayanti ${ }^{2)}$ \\ ${ }^{1,2}$ Fakultas Tarbiyah dan Keguruan UIN Alauddin Makassar \\ st.hasmiah.mustamin@uin-alauddin.ac.id ${ }^{1}$, andi.kusumayanti@uin-alauddin.ac.id ${ }^{2)}$
}

\begin{abstract}
Abstrak
Penelitian ini bertujuan untuk mengetahui kemampuan pemahaman konsep matematika melalui model pembelajaran auditory intellectually repetition pada siswa kelas VIII MTs Negeri 1 Makassar. Jenis penelitian ini adalah quasi eksperiment, dengan teknik pengumpulan data menggunakan tes, dokumentasi, dan wawancara. Populasi dalam penelitian ini adalah seluruh siswa kelas VIII MTs Negeri 1 Makassar sebanyak 40 orang yang terdiri dari 10 kelas. Teknik pengambilan sampel yang digunakan adalah simple random sampling. Sampel yang terpilih kelas VIII.4 sebagai kelas kontrol dan kelas VIII.5 sebagai kelas eksperimen. Teknik analisis data yang digunakan adalah analisis deskriptif dan inferensial. Hasil penelitian diperoleh bahwa:(1) kemampuan pemahaman konsep matematika melalui model pemberlajaran auditory intellectually repetition pada siswa kelas VIII MTs Negeri 1 Makassar sebesar 27,50\% berada pada kategori sedang, sedangkan tanpa menggunakan model pembelajaran auditory intellectually repetition sebesar 27,50\% pada kategori rendah, (2) terdapat perbedaan kemampuan pemahaman konsep matematika yang menggunakan model pembelajaran auditory intellectually repetition dan tanpa menggunakan model auditory intellectually repetition pada siswa kelas VIII MTs Negeri 1 Makassar.
\end{abstract}

Kata Kunci: Auditory Intellectually Repetition, Kemampuan Pemahaman Konsep

\section{Pendahuluan}

Faktor utama yang harus diperhatikan dalam melaksanakan pengembangan sumber daya manusia adalah peningkatan mutu pendidikan. Pendidikan dikatakan berkualitas bila proses belajar mengajar dapat berjalan lancar, efektif, efisien dan ada interaksi antara komponen-komponen yang terkandung dalam sistem pengajaran. Belajar adalah suatu proses perubahan di dalam diri seseorang untuk mengubah tingkah lakunya dalam berpikir, bersikap dan berbuat. Proses pembelajaran akan berjalan efektif apabila seluruh komponen yang terkait didalamnya saling mendukung dalam tercapainya tujuan pembelajaran. Komponen-komponen itu berupa materi pembelajaran, metode mengajar, media, dan evaluasi (Sadiman, 2003).

Matematika merupakan salah satu komponen yang memiliki peranan penting dalam pendidikan, namun sampai sekarang ini masih banyak siswa yang berpikiran bahwa matematika merupakan mata pelajaran yang sangat sulit dan tidak menyenangkan. Penyebabnya karena dalam pelajaran matematika banyak terdapat rumus-rumus yang mesti dihafalkan dan memerlukan pemahaman konsep yang baik. Pemahaman konsep yang baru diperlukan prasyarat pemahaman konsep sebelumnya, sehingga pengetahuan yang diperoleh siswa itu dibangun atau dikonstruksi menurut pengalaman belajar masing-masing sesuai tahap perkembangan dan lingkungan sekitarnya.

Mengingat pentingnya peranan matematika ini, maka upaya untuk meningkatkan sistem pengajaran matematika selalu menjadi perhatian, khususnya bagi pemerintah dan ahli pendidikan matematika. Salah satu upaya nyata yang telah dilakukan pemerintah terlihat pada penyempurnaan kurikulum matematika. Ditetapkannya Undang-Undang Nomor 20 tahun 2003 tentang Sistem 
Pendidikan Nasional dan Peraturan Pemerintah Nomor 6 tahun 2007 tentang Standar Nasional Pendidikan membawa implikasi terhadap sistem dan penyelenggaraan pendidikan termasuk pengembangan dan pelaksanaan kurikulum. Kebijakan pemerintah tersebut mengamanatkan kepada setiap satuan pendidikan dasar dan untuk mengembangkan Kurikulum Tingkat Satuan Pendidikan (KTSP).

Salah satu tujuan Kurikulum KTSP pelajaran matematika yaitu agar peserta didik memiliki kemampuan memahami konsep matematika, menjelaskan keterkaitan antar konsep dan mengaplikasikan konsep atau algoritma, secara luwes, akurat, efisien, dan tepat, dalam pemecahan masalah. Pembelajaran matematika pada saat ini, sangat banyak bahan ajar yang dibebankan kepada guru untuk disampaikan kepada siswa. Pembelajaran yang berfokus ke guru inilah yang dapat mengakibatkan banyaknya siswa mengalami kesulitan dalam menangkap konsep matematika yang diajarkan oleh guru. Mengajar hanya sekedar transfer pengetahuan dari guru ke siswa. Siswa hanya menghafal dan mengingat rumus-rumus, padahal matematika lebih bersifat abstrak. Pembelajaran seperti ini dapat menjadikan matematika akan terkesan lebih sulit dan membosankan serta kurangnya pemahaman siswa terhadap konsep matematika.

Untuk mencapai tingkat pemahaman konsep yang optimal, tidak hanya dapat memakai variasi model pembelajaran sebagai jalan satu-satunya akan tetapi dilihat dari aspek jenis kecerdasan yang dimiliki oleh setiap siswa. Pelaksanaan pembelajaran matematika di MTs Negeri 1 Kota Makassar masih menggunakan model pembelajaran yang memusatkan semuanya kepada guru. Guru berperan sebagai penyampai informasi dan menganggap siswa mampu menyimak dan memahami setiap informasi yang disampaikan kepadanya. Model pembelajaran tersebut digunakan secara menoton dan tanpa adanya variasi sama sekali serta terkadang keluar dari sintaks model pembelajaran yang diterapkan. Hal ini menyebabkan keterhambatan siswa dalam memahami setiap materi atau topik pembelajaran yang mereka pelajari sehingga berefek pada hasil belajar siswa yang tidak meningkat atau bisa saja menurun (Hasil wawancara guru matematika, Nurwati pada tanggal 29 April 2018).

Hal tersebut dibuktikan dengan data ulangan harian yang dilaksanakan sebanyak tiga kali. Nilai yang diperoleh siswa masih banyak di bawah standar kelulusan dengan KKM sebesar 75. Selain itu, diperoleh informasi bahwa guru menerapkan model pembelajaran yang kurang efektif sehingga siswa merasa kesulitan dalam memahami dan menyerap setiap topik atau materi yang diberikan. Ditambah lagi dalam pelaksanaannya, model pembelajaran yang beliau terapkan hanya didominasi oleh siswa yang paham akan materi yang diberikan sehingga pemahaman akan pembelajaran matematika itu sendiri hanya tersampaikan ke beberapa siswa saja dan yang lainnya menjadi pasif bahkan sekedar menjadi pelengkap semata.

Lambat laun membuat siswa menjadi malas dan hanya bergantung kepada temannya yang dianggap pintar. Kurangnya ketertarikan siswa pada penerapan model inilah yang membuat mereka sulit dalam memahami konsep-konsep matematika di setiap topik atau materi yang diberikan oleh guru sehingga menyebabkan hasil belajar mereka menjadi menurun. Tindakan perbaikan untuk mengatasi permasalahan tersebut di atas sangat diperlukan agar kemampuan pemahaman konsep dan hasil belajar matematika siswa meningkat. Salah satu model pembelajaran yang dapat diterapakan adalah model pembelajaran AIR.

Model pembelajaran AIR merupakan model pembelajaran yang menempatkan guru sebagai fasilitator dan siswa ditempatkan sebagai pusat perhatian utama dalam kegiatan pembelajaran melalui tahapan-tahapannya. Siswa secara aktif membangun sendiri pengetahuannya secara pribadi maupun kelompok. Guru bertanggung jawab penuh dalam mengidentifikasi tujuan pembelajaran, struktur 
materi, dan keterampilan dasar yang akan diajarkan. Kemudian menyampaikan pengetahuan kepada siswa, memberikan pemodelan atau demonstrasi, memberikan kesemptan pada siswa untuk berlatih menerapkan konsep atau keterampilan yang telah dipelajari, dan memberikan umpan balik.

Model pembelajaran AIR terdiri atas auditory, intellectually, dan repetition. Auditory berarti belajar melalui mendengarkan, menyimak, berbicara, presentasi, argumentasi, mengemukakan pendapat dan menanggapi (Suherman, 2003). Intellectually berarti belajar harus menggunakan kemampuan berpikir, konsentrasi pikiran, dan berlatih menggunakannya melalui bernalar, menyelidiki, mengidentifikasi, menemukan, mencipta, mengkonstruksi, memecahkan masalah dan menerapkan. Repetition berarti pengulangan dengan tujuan memperdalam dan memperluas pemahaman siswa yang perlu dilatih melalui pengerjaan soal, pemberian tugas dan kuis.

Pengulangan dalam pembelajaran bertujuan untuk memberi pemahaman siswa secara mendalam dengan memberikan soal dalam bentuk kuis atau latihan agar siswa dapat lebih berlatih menggunakan pengetahuan yang diperoleh dalam menyelesaikan soal dan mengingat apa yang telah diterimanya. Sedangkan pemberian kuis bertujuan untuk menyiapkan siswa dalam menghadapi ujian dan melatih daya ingatnya. Pengulangan dalam kegiatan pembelajaran masih sangat diperlukan supaya dapat menumbuhkan kesadaran siswa untuk bersedia mengerjakan soal/latihan yang berulang. Pengulangan yang diberikan bukan berarti diberikan dengan bentuk pertanyan atau soal yang sama melainkan dalam bentuk yang bervariatif sehingga siswa tidak merasa bosan.

Adapun langkah-langkah dalam model pembelajaran AIR sebagai berikut: (1) tahap auditory; pada tahap ini siswa dibagi dalam beberapa kelompok kecil kemudian diberikan LKS untuk dikerjakan secara berkelompok dan apabila siswa kurang memahami soal tersebut maka akan bertanya pada guru, (2) tahap intellectually; pada tahap ini guru membimbing kelompok belajar siswa dalam menyelesaikan soal dan mempresentasikan hasil pekerjaannya, (3) tahap repetition; pada tahap ini guru memberi soal/latihan kepada siswa secara individu dan dengan bantuan guru, siswa mengerjakan soal tersebut serta menyimpulkan materi yang telah dibahas. (Aris Shohimin, 2016).

Tahapan-tahapan dalam model pembelajaran AIR meliputi: (1) fase Auditory: indera telinga digunakan dalam belajar dengan cara mendengarkan, menyimak, berbicara, mengemukakan pendapat, menanggapi, presentasi dan argumentasi, (2) fase Intellectually: kemampuan berpikir perlu dilatih melalui latihan bernalar, mengkonstruksi, menerapkan gagasan, mengajukan pertanyaan dan menyelesaikan masalah, (3) fase Repetition: guru bersama siswa melakukan pengulangan materi melalui kuis, tugas pekerjaan rumah agar pemahaman siswa lebih luas dan mendalam. (Karunia Eka Lestari dan Mokhammad Ridwan Yudhanegara, 2015).

Pemahaman terhadap konsep-konsep matematika merupakan bagian yang sangat penting dalam proses pembelajaran karena matematika terdiri dari berbagai konsep yang tersusun secara hierarkis. konsep merupakan bagian dari materi pembelajaran yang memiliki makna penting untuk dipelajari bagi perkembangan intelektual siswa. Pemahaman konsep merupakan merupakan bagian dari materi pembelajaran yang memiliki makna penting untuk dipelajari bagi perkembangan intelektual siswa. Pemahaman konsep adalah kemampuan siswa dalam memahami konsep suatu materi matematika yang disampaikan oleh guru, dalam hal ini terkait kemampuan siswa dalam mengubah penjelasan guru menjadi informasi yang digunakan untuk menyelesaikan soal secara matematis. Penguasaan konsep sangat dibutuhkan oleh siswa dalam pembelajaran, karena konsep merupakan suatu medium yang menghubungkan subjek penahu atau siswa dengan objek yang diketahui. Seorang siswa harus lebih dahulu mengenali dan mengerti konsep materi agar dapat memahami suatu materi pelajaran. 
Menurut Skemp, pemahaman konsep matematika terdiri atas: (1) Pemahaman instrumental; kemampuan siswa mengingat kembali pengetahuan tentang fakta dasar, istilah, dan menggunakan halhal yang bersifat rutin. Pada hakikatnya siswa tahu penggunaan konsep yang pernah diterimanya meskipun dia tidak mengerti mengapa dilakukan demikian. (2) Pemahaman relasional; kemampuan siswa menerapkan dengan tepat suatu ide matematika yang bersifat umum pada hal yang khusus atau situasi baru (Sumarno, 1987). Jika dilihat dari kemampuan pemahaman siswa dalam pelajaran matematika secara umum, mereka sebagian besar dapat digolongkan dalam pemahaman instrumental. Hanya sebagian kecil saja dari siswa telah memiliki pemahaman relasional memiliki dasar yang lebih kokoh dalam pemahamannya. Siswa yang lupa akan rumus dari suatu materi namun dia tahu akan konsep dari materi itu maka siswa siswa tersebut akan bisa menyelesaikan soal tersebut dengan cara yang lain. Menurut Depdiknas (2003), pemahaman konsep merupakan salah satu kecakapan atau kemahiran matematika yang diharapkan dapat tercapai dalam belajar matematika yaitu dengan menunjukkan pemahaman matematika yang dipelajari, menjelaskan keterkaitan antar konsep dan mengaplikasikan konsep atau algoritma secara luwes, akurat, efesien dan tepat dalam pemecahan masalah.

Menurut Hiebert dan Carpenter, pengajaran yang menekankan pada pemahaman konsep mempunyai keuntungan sebagai berikut: (1) pemahaman memberikan generative artinya apabila seorang telah memahami suatu konsep, maka pengetahuan itu akan mengakibatkan pemahaman yang lain karena adanya jalinan antar pengetahuan yang dimiliki siswa sehingga setiap pengetahuan baru melaui keterkaitan dengan pengetahuan yang sudah ada sebelumnya, (2) pemahaman memacu ingatan artinya suatu pengetahuan yang telah dipahami dengan baik akan diatur dan dihubungkan secara efektif dengan pengetahuan-pengetahuan yang lain melalui pengorganisasian skema atau pengetahuan secara lebih efisien di dalam struktur kognitif berfikir sehingga pengetahuan itu lebih mudah diingat, (3) pemahaman mengurangi banyaknya hal yang harus diingat artinya jalinan yang terbentuk antara pengetahuan yang satu dengan yang lain dalam struktur kognitif siswa yang mempelajarinya dengan penuh pemahaman merupakan jalinan yang sangat baik, (4) pemahaman meningkatkan transfer belajar artinya pemahaman suatu konsep matematika akan diperoleh siswa yang aktif menemukan keserupaan dari berbagai konsep tersebut, hal ini akan membantu siswa untuk menganalisis apakah suatu konsep tertentu dapat diterapkan untuk suatu kondisi tertentu, dan (5) pemahaman mempengaruhi keyakinan siswa artinya siswa yang memahami matematika dengan baik akan mempunyai keyakinan yang positif yang selanjutnya akan membantu perkembangan pengetahuan matematikanya (Dafril, 2011).

Untuk mencapai pemahaman konsep siswa dalam matematika bukanlah suatu hal yang mudah karena pemahaman terhadap suatu konsep matematika dilakukan secara individual. Setiap siswa mempunyai kemampuan yang berbeda dalam memahami konsep-konsep matematika. Namun demikian peningkatan pemahaman konsep matematika perlu diupayakan demi keberhasilan siswa dalam belajar. Salah satu upaya untuk mengatasi permasalahan tersebut, guru dituntut untuk profesional dalam merencanakan dan melaksanakan pembelajaran. Oleh karena itu, guru harus mampu mendesain pembelajaran matematika dengan metode, teori atau pendekatan yang mampu menjadikan siswa sebagai subjek belajar bukan lagi objek belajar. Dari uraian di atas, dapat disimpulkan bahwa pemahaman konsep adalah kemampuan siswa dalam menyerap pengertianpengertian seperti mampu mengungkapkan suatu materi yang disajikan ke dalam bentuk yang lebih dipahami, mampu memberikan interpretasi dan mengaplikasikannya. 


\section{Metode Penelitian}

Penelitian ini dilaksanakan di MTs Negeri 1 Makassar. Pendekatan yang digunakan adalah pendekatan kuantitatif dengan jenis penelitian quasi experiment. Populasi dalam penelitian ini seluruh siswa kelas VIII tahun ajaran 2018/2019 yang terdiri dari 13 kelas. Teknik pengambilan sampel yang digunakan adalah simple random sampling dengan alasan seluruh siswa kelas VIII bersifat homogen. Seiring dengan pendapat Karlinger (2006), simple random sampling adalah metode penarikan dari sebuah populasi dengan cara tertentu sehingga setiap anggota populasi memiliki peluang yang sama untuk terpilih atau terambil. Sampel yang terpilih adalah siswa kelas VIII.5 sebagai kelas eksperimen sebanyak 40 siswa dan kelas VIII A sebagai kelas kontrol sebanyak 40 siswa.

Pengumpulan data pada penelitian ini menggunakan teknik tes berupa soal uraian berjumlah lima soal yang mengacu pada indikator-indikator pemahaman konsep yang telah ditetapkan yaitu kemampuan dalam menerjemahkan soal ke dalam bentuk lain, mengidentifikasikan hal-hal yang relevan dengan suatu konsep yang tepat, mampu menyimpulkan suatu konsep dan menggunakannya dalam perhitungan matematis, menemukan kembali suatu konsep yang belum diketahui sebelumnya berlandaskan pada pengetahuan dan pengalaman, mendefinisikan atau mengungkapkan suatu konsep dengan cara kalimat sendiri namun tetap memenuhi ketentuan berkenaan dengan gagasan konsep. Tes diberikan untuk mengetahui pemahaman konsep matematika siswa, baik pada kelas kontrol maupun kelas eksperimen.

Kategorisasi pemahaman konsep matematika siswa di bagi dalam 5 kategori yaitu sangat tinggi, tinggi, sedang, rendah, dan sangat rendah. Data yang diperoleh dari hasil penelitian, diolah dengan menggunakan teknik analisis statistik deskriptif dan inferensial. Analisis statistik deskriptif digunakan untuk mengetahui gambaran kemampuan pemahaman konsep matematika siswa, sedangkan analisis statistik inferensial untuk mengetahui ada atau tidak perbedaan kemampuan pemahaman konsep matematika melalui model pembelajaran AIR.

\section{Hasil}

\subsection{Hasil Analisis Deskriptif}

Berikut ini data hasil analisis deskriptif yang diperoleh melalui test kemampuan pemahaman konsep matematika yang diberikan pada kelas eksperimen dengan menggunakan model pembelajaran AIR pada siswa kelas VIII MTs Negeri 1 Makassar sebagai berikut.

Tabel 1. Deskripsi Kemampuan Pemahaman Konsep Kelas Eksperimen

\begin{tabular}{lcc}
\hline \multicolumn{1}{c}{ Kategori } & Frekuensi & Persentase \\
\hline Sangat Rendah & 3 & 7,50 \\
Rendah & 10 & 25,00 \\
Sedang & 11 & 27,50 \\
Tinggi & 9 & 22,50 \\
Sangat Tinggi & 7 & 17,50 \\
Jumlah & 40 & 100,00 \\
\hline
\end{tabular}

Berdasarkan tabel 1,pada kelas eksperimen sebanyak 11 (27,50\%) siswa kelas VIII MTs Negeri 1 Makassar memiliki kemampuan pemahaman konsep matematika setelah menggunakan model pembelajaran AIR berada pada kategori sedang. Sedangkan data hasil analisis deskriptif 
kemampuan pemahaman konsep matematika tanpa menggunakan model pembelajaran AIR pada siswa kelas VIII MTs Negeri 1 Makassaryang diperoleh melalui test pada kelas kontrol dapat dilihat pada tabel berikut.

Tabel 2. Deskripsi Kemampuan Pemahaman Konsep Kelas Kontrol

\begin{tabular}{lcc}
\hline Kategori & Frekuensi & Persentase \\
\hline Sangat Rendah & 4 & 10,00 \\
Rendah & 11 & 27,50 \\
Sedang & 9 & 22,50 \\
Tinggi & 8 & 20,00 \\
Sangat Tinggi & 8 & 20,00 \\
\hline Jumlah & 40 & 100,00 \\
\hline
\end{tabular}

Berdasarkan tabel 2, pada kelas kontrol sebanyak 11 (27,50\%) siswa kelas VIII MTs Negeri 1 Makassar memiliki kemampuan pemahaman konsep matematika tanpa menggunakan model pembelajaran AIR berada pada kategori rendah.

\subsection{Hasil Analisis Inferensial}

Untuk mengetahui ada atau tidaknya perbedaan kemampuan pemahaman konsep matematika melalui model pembelajaran AIR pada siswa kelas VIII MTs Negeri 1 Makassar maka digunakan teknik analisis varians (ANOVA). Hasil analisis uji statistik diperoleh $F_{\text {hitung }}$ 7,09 $>F_{\text {tabel }} 3,97$ dan nilai sig. $<\alpha=0,009<0,05$. Ini berarti terdapat perbedaan kemampuan pemahaman konsep matematika yang menggunakan model pembelajaran (AIR) dan tanpa menggunakan model pembelajaran (AIR) pada siswa kelas VIII MTs Negeri 1 Makassar.

\section{Pembahasan}

Berdasarkan hasil uji statistik diperoleh kesimpulan bahwa terdapat perbedaan kemampuan pemahaman konsep matematika yang menggunakan model pembelajaran (AIR) dan tanpa menggunakan model pembelajaran (AIR) pada siswa kelas VIII MTs Negeri 1 Makassar. Hal ini berarti bahwa kemampuan pemahaman konsep matematika lebih tinggi jika diterapkan model pembelajaran (AIR) dibandingkan dengan tanpa menerapkan model pembelajaran (AIR) pada siswa kelas VIII MTs Negeri 1 Makassar.

Perbedaan ini disebabkan karena dalam model pembelajaran AIR terdapat tiga aspek yang harus diintegrasikan yaitu auditory, intellectually, dan repetition sehingga siswa dapat memiliki pengalaman yang banyak untuk menemukan sesuatu dalam menjawab permasalahan. Siswa dapat juga melakukan berbagai jenis kegiatan antara lain saling bertukar informasi yang didapatkan, mengeluarkan pendapat tentang apa yang dipelajari sehingga siswa akan menghasilkan suatu gagasan yang kreatif.

Pada tahap auditory, siswa dibagi dalam 4-5 orang kemudian diminta untuk mengerjakan Lembar Kerja Siswa (LKS) secara berkelompok. Sebelum siswa mengerjakan LKS, terlebih dahulu guru memberikan penjelasan singkat mengenai cara menyelesaikan soal yang berkaitan dengan sistem persamaan linear dua variabel (SPLDV) dan siswa yang kurang memahami soal tersebut maka akan bertanya pada guru. Tahap intellectually; guru membimbing kelompok belajar siswa dalam menyelesaikan soal dan meminta perwakilan kelompok untuk mempresentasikan hasil diskusinya. 
Sedangkan pada tahap repetition, guru memberi soal/latihan kepada siswa secara individu dan siswa membuat kesimpulanmengenai materi yang telah dipelajari. Dengan adanya latihan akan membantu siswa dalam proses mengingat, karena semakin lama informasi itu tinggal dalam memori jangka pendek, maka semakin besar kesempatan memori tersebut ditransfer ke dalam memori jangka panjang.

Tingginya pemahaman konsep matematika siswa juga disebabkan adanya kegiatan pengulangan, pendalaman, dan pemantapan terhadap soal/latihan yang diberikan kepada siswa agar dapat mempertahankan informasi yang masuk ke dalam otaknya dan dapat membantu dalam proses mengingat. Semakin lama informasi tersebut tinggal dalam memori jangka pendek, maka akan semakin besar kesempatan memori tersebut ditransfer ke memori jangka panjang.

Otak manusia memang menyukai aktifitas atau kegitan yang berulang-ulang. Pengulangan dalam pembelajaran matematika bertujuan untuk memberi pemahaman siswa secara mendalam agar siswa dapat lebih berlatih menggunakan pengetahuan yang diperoleh dan mengingat apa yang telah diterimanya serta otaknya juga mampu dalam menerima konsep-konsep matematika sehingga siswa menjadi lebih termotivasi belajar.

Menurut Magnesen, menjelaskan bahwa otak manusia menyenangi 7 hal yaitu otak manusia menyenangi aktifitas yang melibatkan semua indera, melibatkan perasaan, sering mengulang-ulang aktifitas yang dilakukan, otak menyenangi proses yang diawal dan diakhir, hal yang berkaitan dengan pertahanan diri, otak menyenangi sesuatu yang menonjol (beda dari yang lainnya) dan intens (sesuatu yang sangat mendalam) (Kezar, 2001).

Sejalan dengan pendapat Suherman (2003) yang menyatakan pengulangan yang tidak membosankan dan disajikan dengan cara yang menarik akan memberikan dampak positif. Menarik artinya bisa berbentuk informasi yang bervariatif dalam pemberian soal/latihan. Teori Thorndike mengemukakan bahwa law of exercise (hukum latihan), yaitu semakin sering suatu tingkah laku diulang/ dilatih (digunakan) maka asosiasi tersebut akan semakin kuat.

Hasil penelitian Yurdiana (2012), mengemukakan bahwa prestasi belajar matematika siswa lebih tinggi yang diajar dengan menggunakan model pembelajaran AIR dibanding dengan menggunakan model pembelajaran konvensional. Penyebabnya karena dalam penerapan model pembelajaran AIR, siswa dilatih pendengaran dan keberaniannya untuk mengeluarkan pendapat, memecahkan berbagai masalah secara kreatif, mengingat kembali materi yang telah dipelajari, dan siswa dapat lebih aktif dan kreatif. Siswa harus dapat memanfaatkan semua panca indera yang dimiliki dalam belajar agar dapat meningkatkan kemampuan pemahaman konsep matematika.

Selain itu, pada pembelajaran yang menggunakan model AIR membuat siswa berpartisipasi aktif, sering mengekspresikan ide-idenya dan dapat termotivasi untuk menemukan suatu jawaban dari permasalahan yang ada serta guru mengenalkan materi yang akan dipelajari pada awal pembelajaran tersebut.

Berdasarkan berbagai pendapat di atas, sangat jelas menggambarkan bahwa siswa yang bisa berkonsentrasi akan bisa mempertajam persepsi atau hal-hal baru yang dipelajari. Ditambah lagi dengan salah satu keunggulan yang sangat tampak dari model pembelajaran AIR adalah terdapat beberapa aspek yang harus diintegrasikan meliputi auditory, intellectually, repetition sehingga secara sekilas siswa memiliki pengalaman banyak untuk menemukan sesuatu dalam menyelesaikan permasalahan. 


\section{Kesimpulan}

Berdasarkan hasil penelitian dan pembahasan sebelumnya, maka dapat ditarik kesimpulan bahwa kemampuan pemahaman konsep matematika siswa kelas VIII MTs Negeri 1 Makassar setelah menggunakan model pembelajaran AIR sebesar 27,50\% berada pada kategori sedang, sedangkan kemampuan pemahaman konsep matematika siswa kelas VIII MTs Negeri 1 Makassar tanpa menggunakan model pembelajaran AIR sebesar 27,50\% berada pada kategori rendah.

Hasil analisis uji statistik diperoleh bahwa terdapat perbedaan kemampuan pemahaman konsep matematika yang menggunakan model pembelajaran AIR dan tanpa menggunakan model pembelajaran AIR pada siswa kelas VIII MTs Negeri 1 Makassar.

\section{Daftar Pustaka}

A. Kezar. 2001. Theory of Multiple Intelligences: Implications for Higher Education., Innov. High. Educ., Vol. 26, No. 2, PP. 141-154.

Depdiknas. 2003. Pedoman Khusus Pengembangan Sistem Penilaian Berbasis Kompetensi SMP. Jakarta: Depdiknas.

Lestari, Karunia Eka dan Mokhammad Ridwan Yudhanegara. 2015. Penelitian Pendidikan Matematika. Cet.1, Bandung: PT. Refika Aditama.

Sadiman, Arif S, dkk. 2003. Media Pendidikan Pengantar, Pengembangan dan Pemanfaatannya. Jakarta: PT. Raja Grafindo Persada.

Sardiman. 2011. Interaksi dan Motivasi Belajar Mengajar. Jakarta: Raja Grafindo.

Shohimin, Aris. 2016. 68 Model Pembelajaran Inovatif dalam Kurikulum 2013. Yogyakarta: Ar-Ruzz Media.

Suherman, Erman. 2003. Strategi Pembelajaran Matematika. Bandung: UPI.

Sugiyono. 2004. Metode Penelitian Pendidikan: Pendekatan Kuantitatif, Kualitatif, dan $R \& D$. Bandung: Alfabeta.

Sumarmo, U. 1987. Kemampuan Pemahaman dan Penalaran Matematik Siswa SMA Dikaitkan dengan Penalaran Logik Siswa dan Beberapa Unsur Proses Belajar Mengajar. Disertasi pada Pascasarjana IKIP Bandung: tidak diterbitkan

Widoyoko, Eko Putro. 2014. Evaluasi Program Pembelajaran. Yogyakarta: Pustaka Pelajar. 